\title{
An empirical study of factors influencing adoption of Internet banking among
}

\author{
students of higher education: Evidence from Pakistan
}

\author{
Abdul Kabeer Kazi ${ }^{\mathrm{a}}$, \\ ${ }^{a}$ Khadim Ali Shah Bukhari Institute of Technology, Karachi, Pakistan
}

\begin{abstract}
This paper investigated the influence of factors on the intention to adopt Internet banking services among students of higher education in Pakistan. Theoretical framework used for this study has been adopted from Technology Acceptance Model (TAM) with four independent variables. Convenience sampling method was used with a total of valid 220 respondents, which included students of Khadim Ali Shah Bukhari Institute of Technology (KASBIT), Karachi, Pakistan. Data was collected through self administered questionnaire of two parts: Demographic and Likert scale multi-item scale for variables under study. Results indicated that convenience, perceived credibility, and perceived usefulness had significant positive influence among students on the intention to adopt Internet banking. The findings from this research would be useful for banks in the subject area, particularly for students in Pakistan.
\end{abstract}

Keywords: Internet banking; students of higher education; technology acceptance model; Pakistan

\section{C) 2013 Published by SSBFNET}

\section{Introduction}

One of the major forces behind the changes happenings to business today is technology, which is creating new products, services market opportunities and developing more information and system oriented business and management processes (Liao and Cheung, 2002). Technology engaged in service organizations boost consumer service value and delivery, reduce expenses, and homogenize nucleus service contributions (Ibrahim et al, 2006; Gounaris et al, 2005).The banking industry has always been innovative and receptive to new technological development in the financial service industry (Ozdemir, Trott, and Hoecht, 2008).

The Internet has an ever-growing importance in the banking sector because of the advantages it brings to both the entities and their customers. Although an information system (IS) overhead is regarded costly and risky, financial institutions are one of the largest investors in IS (Mashhour and Zaatreh, 2008). Because of challenging business processes in the financial services, banks have been harried to initiate alternate delivery channel to pull consumers and improve consumers' awareness. It has been observed in the developed countries in general and developing countries in particular that during the last decade, electronic banking has enjoyed remarkable multidimensional growth and better services as compared to traditional banking system (Gonza'lez et al, 2008).

In Pakistan, banking sector has adopted information and communication technology (ICT) in its early stages and offered customers through Internet a variety of online services with more convenience for accessing information and

\footnotetext{
${ }^{\text {a }}$ Corresponding author, Abdul Kabeer Kazi, E-mail address: conference.kazi@yahoo.com
} 
making transactions. According to Internet World Statistics (2013) the number of Internet users in Pakistan as of June 2012 is over 12.1 million with $15.3 \%$ population penetration.

Pakistan has witnessed an increase in the actual use of Internet banking services, as consumers performed financial transactions. According to (Azeem, 2012) service utility augmented by 89 percent and quantity of money grew by 112 percent in first quarter of financial year 2011-12. The State Bank of Pakistan's "Payment Systems Review" stated that Rs 84.85 billion was transferred through Internet banking in Pakistan in Jul-Sep 2011, with 1.6 million numbers of transactions (Azeem, 2012).

But despite all the opportunities and benefits created by the Internet banking, there are still many challenges that are present in the financial sector. There are also some limitations of Internet banking as it requires awareness, knowledge and skills to operate it.

A lot of research has been conducted in recent past to study the adoption factors of Internet Banking in Pakistan. (Kaleem and Ahmad, 2008) studied the advantages of Internet banking among employees of Pakistani public and private banks. In another survey of 235 Pakistani bank consumers, it was found that usefulness of Internet banking over conventional banking as the dominant factor to adopt this service. Almost $50 \%$ of consumers shifted from traditional banking system to Internet banking (Qureshi, Zafar, and Khan, 2008). A study by (Khan, 2007) of three Pakistani firms of their intention to adopt Internet banking, lack of trust in Internet banking system, and lack of confidence in making big amount transfer over Internet were the salient factors which inhibit the adoption rate.

Clearly, in order to grow consumer Internet banking adoption, banks must make key improvements that address consumer concerns. Thus, it would behoove financial institutions to gain an understanding of the key factors that influence consumer Internet banking adoption.

Therefore, the purpose of this study is to investigate factors usage of Internet banking service among students of higher education in Pakistan. Internet banking acceptance will be studied using the factors that are critically successful, referring to the idea that consumers are using Internet banking directly. Hence, more knowledge on the factors that affect Internet banking adoption is needed in order to better understand and facilitate the adoption.

Based on the aforementioned, the researcher examined the factors that influence students of higher education in Pakistan to use the Internet for their banking transactions. In order to address the research issues in this paper, the researcher reviewed existing works on Internet banking adoption including research methods appropriate for this paper, and then applied them to the context of Pakistan.

The remainder of the paper is set out in six sections. The first section introduces the research topic, and in second section literature review has been presented on adoption of Internet banking. Third section highlighted research methodology that was employed. Fourth, statistical analysis on data collected through survey questionnaire is presented, and in fifth section the researcher discussed the main findings and draw implications for theory and practice. Sixth and finally, the researcher concluded the paper, with research limitation, and guidelines for future research.

\section{Literature Review}

One of the most important theories used by researchers when studying consumer's intention to adopt Internet banking is Technology Acceptance Model (TAM), originally proposed by (Davis, 1989). TAM was considered as a robust instrument for studying and researching the adoption and usage of Internet Banking, by looking at the demand side issues of IT/IS usage (Hewer and Howcroft, 1999; Rogers, 1995), rather than the supply, or developer's perspective, as is often the case. Overall, TAM can successfully guide technology implementation, developments and innovations within the area of Internet Banking. 


\subsection{Perceived Usefulness}

Davis (1989) defined perceived usefulness as "the degree to which a person believes that using a particular system would enhance his or her job performance". The importance of perceived usefulness has been widely recognized in the field of e-banking (Polatoglu and Ekin, 2001). There is also broad research that presents evidence of the significant impact of perceived usefulness on user acceptance of e-banking (Davis et al., 1989; Venkatesh and Davis, 1996; Agarwal and Prasad, 1999; Venkatesh, 1999, 2000). Adams et al. (1992) and Davis et al. (1989) reported that user acceptance of computer systems is driven to a large extent by perceived usefulness. Moreover, Pikkarainen et al., (2004) previously found that perceived usefulness had a direct effect on internet banking usage. People use online banking services because they find that using banking web sites enhances the productivity of their banking activities and that they are useful for performing financial transactions (Singh, 2012). Wang et al. (2003) discovered that perceived usefulness effect Taiwan people's intentions to adopt e-banking systems significantly. Hence, the greater the perceived usefulness of using e-banking services, the more likely that e-banking will be accepted by users (Polatoglu and Ekin, 2001). A customer will have a positive attitude towards Internet banking when customers feel that using Internet banking provide benefits for them (Al-Shomali, et al. 2008).

Hence, the following hypothesis has been proposed:

$\mathrm{H}_{1}$ : PU has a positive influence on the intention to adopt Internet banking services among students of higher education in Pakistan.

\subsection{Perceived Ease of Use (PEOU)}

In TAM, an individual's belief develops the intention to use the system. According to Davis (1989) PEOU refers to the degree to which a person believes that using a particular system would be free of effort. Similarly, Zeithaml et al. (2002) stated that the degree to which an innovation is easy to understand or use could be considered as perceived ease of use. Hainudin (2007) and Wang et al (2003) found that PEOU has a positive effect on behavioral intention to use the Internet banking. Also with less complexity in interacting with system, positive attitude could be developed subsequently towards intention and behavior. Guriting and Ndubisi (2006) found that PEOU had a significant positive effect on behavioral intention to use online banking in Malaysia. Several researchers have proposed that a system that is easy to use will be more widely accepted than the one that is not as easy to use (Ndubisi et al, 2001; Selim, 2003). Based on these findings, it is highly expected that the general causalities found in TAM are also applicable to Internet banking services.

Hence, the following hypothesis has been proposed:

$\mathrm{H}_{1}$ : PEOU has a positive influence on the intention to adopt Internet banking services among students of higher education in Pakistan.

\subsection{Perceived Credibility (PCRED)}

According to Jacoby and Kaplan (1972), perceived credibility refers to a user feels the certainty and pleasant consequences of using an electronic application service, when there is no financial risk, physical risk, functional risk, social risk, time-loss risk, opportunity cost risk, and information risk. Perceived Credibility is "the belief that the promise of another can be relied upon even under unforeseen circumstances" (Suh and Han, 2002). Daniel (1999) and O' Connell (1996) found that security concern was important in affecting the acceptance and adoption of new technology or innovation.

For credibility it is necessary for bank to ensure its good reputation and must give confidence to customer about its services. There are many fears in the mind of customer but if the credibility of that particular bank is at high level than the customer will be assured that his transactions with that bank are safe and there is not much to worry about. If the 
credibility of bank is below par than the chances of risk will be certainly increased enabling customer not to trust easily (Hassan et al, 2012).

Perceived credibility consists of two important elements: privacy and security. Security refers to the protection of information or systems from unauthorized intrusions (Egwali, 2008). Fear of inadequate security is one of the factors that have been identified as impediments to the growth and development of e-Commerce including electronic banking adoption (Ezeoha, 2005). Perceived credibility is about personal belief that a user has in the system to carry out a transaction securely and maintain the privacy of personal information (Adesina and Ayo, 2010). According to Hanudin (2007), perceived credibility is a determinant of behavioral intention to use an information system. Ramayah and Ling (2002) found that Internet banking users were very concerned about security and majority of them were using Internet banking for accounts enquiry only due to the credibility concern.

Hence, the following hypothesis has been proposed:

$\mathrm{H}_{3}$ : PCRED has a positive influence on the intention to adopt Internet banking services among students of higher education in Pakistan.

\subsection{Convenience (CONV)}

Copeland (1923) defined convenience goods as a class of consumer products that were intensively distributed and required minimal time and physical and mental effort to purchase. Some later definitions of convenience also focused on resources such as time and effort required of the consumer in shopping for a product (Brown, 1990). Other researchers, however, expanded the concept of convenience to incorporate non-shopping activities. It is related to the visual view of the Internet compared to telephone banking (Black et al., 2002).Convenience is one of the most beneficial features of Internet banking (Liao and Cheung, 2002; Daniel, 1999). People can bank online to pay bills, check balances, transfer funds, apply for auto loans and mortgages, and use other complementary services at the tip of a finger anytime from anywhere (Yu and Lo, 2007; Ramsaran, 2003). Lichtenstein and Williamson (2006) indicate that time saving and 24/7 access appear to be the most important aspects of the convenience of Internet banking services. Devlin (1995) explains that as people become more time and leisure conscious, the convenience aspects of Internet banking will be increasingly valued.

Therefore, the following hypothesis has been proposed.

$\mathrm{H}_{4}$ : Convenience has a positive influence on the intention to adopt Internet banking services among students of higher education in Pakistan.

\section{Methodology}

This present study focused on how the students of higher education in Pakistan perceived the adoption of Internet banking. The main motivation for this research was that there was no study conducted that involved higher education students' intention to adopt Internet banking in Pakistan. Therefore, a current enrollment of 1600 students of Khadim Ali Shah Bukhari Institute of Technology (KASBIT), Karachi Pakistan, as of August 2012 was the population for the study. A convenience sampling method was used as survey instrument for this study. Convenience sampling is a type of non-probability sampling which involves the sample being drawn from that part of the population which is close to hand. Convenience sampling method is cost effective, and this method has been used in many information systems research (Eze et al, 2011).

The independent variables of this study are perceived usefulness (PU), perceived ease of use (PEOU), perceived credibility (PCRED) and convenience (CONV). These independent variables may be the determinants that influence dependent variable, i.e. intention to adopt (ADOP) Internet banking among students of higher education in Pakistan. A self-administered questionnaire was used in this research, which consists of two sections. The first section contains the 
demographic information such as gender, age group, program of study, and the second section consists of the conceptual variables identified earlier. The conceptual variables were measured by using multi-item seven point Likert scales. For example, "1" denoted as strongly disagree, "2" denoted as disagree, "3" denoted as somewhat disagree, "4" as neutral, " 5 " as somewhat agree, " 6 " as agree, and "7" as strongly agree. The questionnaire items were adapted from different sources. PU was measured with five items adapted from (Goodhue and Thompson, 1995; Wang et al, 2003). PEOU with five items was adapted from (Nysveen et al, 2005; Goodhue and Thompson, 1995). PCRED with five items was adapted from (Liao and Cheung, 2002; Jaruwachirathanskul and Fink, 2005). CONV with five items was adopted from (Cunningham et al, 2005). Finally, students' intention to adopt Internet banking with five items was adapted from (Venkatesh and Morris, 2000).

The questionnaire was distributed to 300 students during classes in morning, evening, and weekend sessions. Out of 300 questionnaires 240 were returned to the researcher. However, 20 questionnaires were removed because they included missing values for at least 1 of the questions. Correlation and multiple linear regression analysis was engaged by researcher to ascertain a set of independent variables; PU, PEOU, PCRED, and CONV, which explains a part of the variance in the dependent variable of behavioral intention to adopt Internet banking services at a significant level and used for hypotheses testing. The data from the 220 valid questionnaires was analyzed using Statistical Package for Social Sciences (SPSS) software version 17.

\section{Data Analysis}

Demographic profile of students for this study includes gender, age group, and program of study. The following Table1 represents the demographic characteristics of the students.

Table No. 1 Demographic Characteristics of the respondents

\begin{tabular}{|l|l|l|l|}
\hline Variable & Classification & Frequency & Percentage \\
\hline Gender & Male & 166 & 75.5 \\
\hline & Female & 54 & 24.5 \\
\hline & & 220 & $100 \%$ \\
\hline Age Group & Up to 25 years & 147 & 66.8 \\
\hline & $26-40$ years & 60 & 27.3 \\
\hline & More than 40 & 13 & 5.9 \\
\hline & & 220 & $100 \%$ \\
\hline Program of Study & BBA & 144 & 65.5 \\
\hline & MBA & 54 & 24.5 \\
\hline & MS/M Phil & 17 & 7.7 \\
\hline & PhD & 5 & 2.3 \\
\hline & & 220 & $100 \%$ \\
\hline
\end{tabular}

Source: This study

The gender distribution of respondents is 75.5 percent for male and 24.5 percent for female. Majority of the respondents were male which is 166 respondents while female is 54 respondents make the grand total respondents are 220.

The breakdown of age groups is dominated by the group of up to 25 which consist of 147 students $(59.4 \%)$. The number of respondents in age group of 26-40 years was 60 students $(27.3 \%)$, and finally there were 13 respondents who were above the age of 40 representing $5.9 \%$ of total 220 student sample for this study.

The breakdown for program of study consists of 144 students of BBA program representing $65.5 \%, 54$ students of MBA program representing 24.5\%, 17 students of MS/M. Phil program representing 7.7\%, and finally 5 students of $\mathrm{PhD}$ program representing $2.3 \%$ of total 220 student sample for this study. 
The following Table No. 2 shows the Cronbach's Alpha value for all variables. Cronbach's Alpha is used to determine the internal reliability of the multi item variables. Nunnally (1967) indicated that a value of 0.7 Cronbach's Alpha or higher is considered acceptable. The statistics show that all variables exhibited values ranging 0.822 to 0.921 , which suggests that the data is reliable and consistent with acceptable research standards.

Table No. 2 Reliability Analysis of variables

\begin{tabular}{|l|l|l|l|}
\hline Variable & No. of Items & Mean Value & Cronbach's Alpha \\
\hline Perceived Usefulness & 5 & 3.975 & 0.896 \\
\hline Perceived Ease of Use & 5 & 3.975 & 0.826 \\
\hline Perceived Credibility & 5 & 4.025 & 0.921 \\
\hline Convenience & 5 & 3.933 & 0.840 \\
\hline Intention to Adopt & 5 & 3.981 & 0.822 \\
\hline
\end{tabular}

Source: This study

The following Table No. 3 shows the correlation matrix of the conceptual variables. A two-tail test at 0.01 level of significance indicates that there are positive relationships among the variables. According to Wong and Hiew (2005) if the value of correlation coefficient is from 0.50 to 1.0 , it is considered strong. There are strong relationships between dependent variable "ADOP" and four independent variables (PU, PEOU, PCRED, and CONV) as the respective correlation is above 0.5 .

Table No. 3 Correlation Matrix

\begin{tabular}{|l|l|l|l|l|l|}
\hline Constructs & ADOP & PU & PEOU & PCRED & CONV \\
\hline ADOP & 1.00 & & & & \\
\hline PU & $0.813^{* *}$ & 1.00 & & & \\
\hline PEOU & $0.723^{* *}$ & $0.712^{* *}$ & 1.00 & & \\
\hline PCRED & $0.846^{* *}$ & $0.838^{* *}$ & $0.749^{* *}$ & 1.00 & $0.840^{* *}$ \\
\hline CONV & $0.837^{* *}$ & $0.806^{* *}$ & $0.792^{* *}$ & 1.00 \\
\hline
\end{tabular}

${ }^{* *}$ Correlation is significant at 0.01 level of significance

Source: This study

Multiple regression analysis is used to analyze the relationship between one dependent variable to several independent variables (Hair et al, 2005). Therefore, the researcher employed multiple regression analysis to test the hypotheses under study. The following Table No. 4 shows the analysis of coefficients for specific relationships.

Table No. 4 Multiple Regression Analysis

\begin{tabular}{|c|c|c|c|c|c|}
\hline Model & \multicolumn{2}{|c|}{$\mathrm{R}=0.886$} & $\mathrm{R}-\mathrm{Square}=0.785$ & $\begin{array}{l}\text { Adj. R Square }= \\
0.781\end{array}$ & \\
\hline Model & \multicolumn{2}{|c|}{ F-Value $=195.851$} & Sig. $=0.000$ & & \\
\hline \multirow{2}{*}{ Model } & \multicolumn{2}{|c|}{ Unstandardized Coefficients } & Standardized Coefficients & \multirow{2}{*}{$\mathrm{t}$} & \multirow{2}{*}{ Sig. } \\
\hline & B & Std. Error & Beta & & \\
\hline Constant & 0.310 & 0.149 & 0.224 & 2.072 & 0.039 \\
\hline PU & 0.215 & 0.060 & 0.224 & 3.598 & 0.000 \\
\hline PEOU & 0.041 & 0.059 & 0.037 & 0.696 & 0.487 \\
\hline PCRED & 0.326 & 0.063 & 0.353 & 5.154 & 0.000 \\
\hline CONV & 0.342 & 0.070 & 0.331 & 4.871 & 0.000 \\
\hline
\end{tabular}

Source: This study 
For the coefficient of correlation, $R$ stated 0.866 , for coefficient of determination, $R^{2}$ stated 0.785 , indicating that 78.5 percent of the variance in dependent variable "ADOP" explained by four independent variables, i.e. PU, PEOU, PCRED, and CONV. The F-statistics for this study was significant at 0.01 level ( $p$-value $<0.01$ ), showing the fitness of the model. The individual model variables indicated that unstandardized coefficients for $\mathrm{PU}$ (p-value $<0.01$ ), PCRED ( -value $<0.01$ ), and CONV (p-value $<0.01$ ) positively and significantly affected dependent variable "ADOP" of Internet banking. However, the independent variable PEOU (p-value $>0.01$ ) had no significant relationship with intention to adopt Internet banking among students of higher education in Pakistan.

Hypotheses $\mathrm{H}_{1}, \mathrm{H}_{3}$ and $\mathrm{H}_{4}$, were supported in that PU, PCRED, and CONV all had a significant effect on the intention to adopt Internet Banking among students of higher education. However, hypothesis $\mathrm{H}_{2}$ was not supported as PEOU had no significant influence on the intention to adopt Internet banking among students of higher education in Pakistan.

\section{Discussion}

The findings in this paper revealed that convenience has the strongest positive significant relationship in examining the intention to adopt Internet banking among students of higher education in Pakistan. This result is consistent in the study by Eastin (2002) and Nasri (2011) where perceived convenience was the strongest predictor of online banking usage. This could be as the students have ready access to Internet; most of their time is spent on studies, so they opt for Internet banking as compared to conventional systems.

This study also revealed that perceived credibility had second most positive significant influence after convenience on the intention to adopt Internet banking among students of higher education in Pakistan. Therefore the result is consistent with previous studies such as Gerrard and Cunningham (2003), Ramayah and Ling (2002), and Sathye (1999) who claimed that perceived credibility was a determinant of intention to adopt Internet banking. Again, as most of the students of higher education are intermediate to expert users of Internet, they generally are somewhat concerned about risks of privacy and security, but overall they believe Internet banking is trustworthy.

The independent variable perceived usefulness included in this study also had a significant positive relationship with intention to adopt Internet banking. The findings indicated that respondents were keen on the benefits a system would offer them if they used it relative to other systems. This result is consistent with several past studies of Venkatesh and Morris (2000), Chiu et al (2005), Hernandez et al. (2011), and Weisberg et al (2011), who claimed that perceived usefulness has a significant relationship with behavioral intention to use an IS. The results of data analysis point out that students of higher education in Pakistan were eager on the benefits Internet banking services would offer them if they used it relative to other systems. Consumers must realize that in today's fact paced life style, the use of Internet related applications should be readily adopted in order to stay abreast with latest trends.

Specifically, the results showed that hypothesis $\mathrm{H}_{2}$ which predicted a positive relationship between perceived ease of use and behavioral intention to adopt Internet banking services was not supported. Similar results of non-significant effect of independent variable perceived ease of use on behavioral intention to adopt Internet based application has been demonstrated in the past. According to (Gefen and Straub, 2000; Gardner and Amoroso, 2004; Saade and Galloway, 2005; and Sihombing, 2007), the factor ease of use would be perceived as less important when analyzed along with factor usefulness. The strong relative importance and usefulness of Internet banking services among students of higher education has over powered the overall effect of ease of use of Internet based application.

\section{Conclusion}

The primary objective of this study was to analyze the determinants affecting intention to adopt Internet banking among students of higher education in Pakistan. This study identified some variables that are more dominant than others in Internet banking adoption. The empirical results showed that the perceived convenience, perceived 
credibility, and perceived usefulness all have significant effects on behavioral intention to use Internet banking. However, perceived ease of use was not a significant factor in the intention to adopt Internet banking.

The outcomes of this research can also be used to help banks better recognize Pakistani students of higher education intention to adopt Internet banking. This could facilitate banks to devise valuable techniques to attract this group to use this service.

One of the limitations of this study was that the respondents were from only one higher education institute, i.e. KASBIT, and may not represent the entire student population of private/public sector universities in Pakistan. Therefore, future research should consider the responses from this population as well. Researchers can compare the results and look the gap in order to further investigate the students of higher education behavioral intention to adopt Internet banking. This will enable a stronger and a more reasonable standpoint on the research issues.

\section{References}

Adams, D. A., Nelson, R. R. and Todd, P. A., (1992). Perceived Usefulness, Ease of Use, and Usage of Information Technology: A Replication, MIS Quarterly, (16): 227-247.

Adesina, A. A., and Ayo, C.K., (2010). An Empirical Investigation of the Level of Users' Acceptance of E-banking in Nigeria, Journal of Internet Banking and Commerce, 15(1).

Agarwal, R. and Prasad, J. (1999). Are individual differences germane to the acceptance of new technologies? Decision Sciences, 30(2): 361-391.

Al-Shomali, S. A., Gholami, R., and Clegg, B., (2008). Internet Banking Acceptance in the Context of Developing Countries: An Extension of the Technology Acceptance Model. European Conference on Management of Technology, Nice, France. September 2008.

Azeem, Y., (2012), "Internet Banking Services On the Rise in Pakistan", PKEconomists, Retrieved from http://pkeconomists.com/internet-banking-services-on-the-rise-in-pakistan

Black, N.J., Lockett, A., Winklhofer, H., and McKechnie, S., (2002). Modeling consumer choice of distribution channels: an illustration from financial services. The International Journal of Bank Marketing, 4: 161-173.

Brown, L. G., (1990). Convenience in services marketing. Journal of Service Marketing, 4: 5359.

Chiu, Y.B., Lin, C.P., and Tang, L.L. (2005). Gender differs: Assessing a model of online purchase intentions in e-tail service. International Journal of Service Industry Management, 16(5): 416-435.

Copeland, M. T., (1923). Relation of consumers' buying habits to marketing methods. Harvard Business Review, 282289.

Cunningham, L. F., Gerlach, J., and Harper, M. D. (2005). Perceived risk and e-banking services: An analysis from the perspective of the consumer, Journal of Financial Services Marketing, 10(2): 165 - 178. 
Daniel, E., (1999), Provision of Electronic Banking in the UK and the Republic of Ireland, International Journal of Bank Marketing, 17(2): 72-82.

Davis, F. D., (1989). Perceived usefulness, perceived ease of use, and user acceptance of information technology. MIS Quarterly, 13(3): 319-340.

Davis, F. D., Bagozzi, R. P. and Warshaw, P. R., (1989). User Acceptance of Computer Technology: A Comparison of Two Theoretical Models, Management Science, 35(8): 982-1002.

Devlin, J. F., (1995). Technology and innovation in retail banking distribution. International Journal of Bank Marketing. 13(4): 19-26.

Egwali, A. O., (2008). Customer Perception of Security Indicators in Online Banking Sites in Nigeria, Journal of Internet Banking and Commerce. 13(3).

Eastin, M. (2002). Diffusion of E-commerce: An Analysis of the Adoption of Four E-commerce Activities. Telemetric and Informatics, 19(3), 251-267.

Eze, U. C., Manyeki, J. K., Yaw, L. H., and Har, L. C., (2011). Factors Affecting Internet Banking Adoption among Young Adults: Evidence from Malaysia, 2011 International Conference on Social Science and Humanity, IPEDR vol.5 (2011) C (2011) IACSIT Press, Singapore.

Ezeoha, A. E., (2005) Regulating Internet Banking In Nigeria: Problems and Challenges - Part 1, Journal of Internet Banking and Commerce, 11(1).

Gardner, C., and Amoroso, D. (2004). Development of an instrument to measure the acceptance of Internet technology by consumers, Proceedings of the $37^{\text {th }}$ Hawaii International Conference on System Sciences - 2004, IEEE

Gefen, D., and Straub, D. W., (2000). The Relative Importance of Perceived Ease of Use in IS Adoption: A Study of E-Commerce Adoption, Journal of the Association for Information Systems. 1(8): 1-28.

Gerrard, P. and Cunningham, J.B. (2003). The Diffusion of Internet Banking among Singapore Consumers, International Journal of Bank Marketing, 21(1): 16-28.

Gonza'lez, M. E., Mueller, R. D., and Mack, R.W., (2008). An alternative approach in service quality: an e-banking case study, The Quality Management Journal, 15(1): 41-60.

Goodhue, D.L. and Thompson, R.L. (1995). Task-technology fit and individual performance, MIS Quarterly, 19(2): 213-236. 
Gounaris, S., Dimitriadis, S., and Stathakopoulos, V., (2005), Antecedents of perceived quality in the context of Internet retail stores, Journal of Marketing Management, 21(7), 669-682.

Guriting, P., and Ndubisi, N.O., (2006). Borneo online banking: evaluating customer perceptions and behavioral intention. Management Research News, 29 (1/2): 6-15.

Hainudin, A. (2007). Internet Banking Adoption among Young Intellectual. Journal of Internet Banking and Commerce, 12(3).

Hair, J. F., Black, W. C., Babin, B. J., Anderson, R. E., and Tatham, R. L., (2005). Multivariate Data Analysis, 6th ed., Englewood Cliffs, NJ: Pearson Prentice-Hall.

Hassan, M. T., Mukhtar, A., Ullah, R. K., Shafique, H., and Rehman, S. U., (2012), Customer Service Quality Perception of Internet Banking, International Journal of Learning \& Development, 2(2): 101-111.

Hernández, B., Jiménez, J., \& Martín, J. (2011). Age, gender and income: do they really moderate online shopping behavior? Online Information Review, 35(1): 113-133.

Hewer, P., and Howcroft, B., (1999). Consumers' distribution channel adoption and usage in the financial services industry: A review of existing approaches. Journal of Financial Services Marketing, 3(4): 344-358.

Ibrahim, E. E., Joseph, M. and Ibeh, K. I. N., (2006), Customers' perception of electronic service delivery in the UK retail banking sector, International Journal of Bank Marketing, 24(7): 475-493.

Internet World Statistics, (2013), http://www.internetworldstats.com/stats3.htm\#asia, Accessed on Jan 18, 2013.

Jacoby, J., and Kaplan, L., (1972). The components of perceived risk. Advances in Consumer Research, 3: 382-383.

Jaruwachirathanskul, B. and Fink, D., (2005) Internet Banking Adoption Strategies for a Developing Country: The Case of Thailand, Internet Research, 15(3): 295-311.

Kaleem, A., and Ahmad, S., (2008). Bankers' Perception of Electronic Banking in Pakistan, Journal of Internet Banking and Commerce, 13(1).

Khan, S., (2007), Adoption Issues of Internet Banking in Pakistani Firms, Unpublished master's thesis, Lulea University of Technology, Sweden.

Liao, Z. and Cheung, M.T., (2002), Internet-based E-Banking and Consumer Attitudes: An Empirical Study, Information and Management, 39(4): 283-295. 
Lichtenstein, S., and Williamson, K., (2006). Understanding consumer adoption of internet banking: an interpretive study in the Australian banking context. Journal of Electronic Commerce Research. 7(2): 50-66.

Mashhour, A., and Zaatreh, Z., (2008), A Framework for Evaluating the Effectiveness of Information Systems at Jordan Banks: An Empirical Study, Journal of Internet Banking and Commerce, 13(1).

Nasri, W., (2011). Factors Influencing the Adoption of Internet Banking in Tunisia, International Journal of Business and Management, 6(8): 143-160

Ndubisi, N. O., Jantan, M. and Richardson, S., (2001). Is the technology acceptance model valid for entrepreneurs? Model testing and examining usage determinants, Asian Academy of Management Journal, 6(2): 31-54.

Nunnally, J. C., 1967. Psychometric Theory ( $1^{\text {st }}$ Ed), New York, McGraw-Hill

Nysveen, H., Pedersen, P. E., and Thorbjørnsen, H. (2005). Intentions to use mobile services: Antecedents and crossservice comparisons. Journal of the Academy of Marketing Science, 33(3): 330-346.

O’ Connel, B. (1996). Australian banking on the Internet - Fact or fiction? The Australian Banker, 12: 212-214.

Ozdemir, S., Trott, P., and Hoecht, A., (2008), Segmenting internet banking adopter and non-adopters in the Turkish retail banking sector, International Journal of Bank Marketing, 26(4): 212-236.

Pikkarainen, T., Pikkarainen, K., Karjaluoto, H. and Pahnila, S., (2004). Consumer acceptance of online banking: an extension of the technology acceptance model, Internet Research, 14(3): 224-235.

Polatoglu, V. N., and Ekin, S. (2001). An Empirical Investigation of the Turkish Consumers' Acceptance of Internet Banking Services. International Journal of Bank Marketing, 19(4): 156-165.

Qureshi, T. M., Zafar, M. K., and Khan, M. B., (2008), Customer Acceptance of Online Banking in Developing Economies, Journal of Internet Banking and Commerce, 13(1).

Ramayah, T., and Ling, K.P., (2002). An exploratory study of Internet banking in Malaysia. The proceedings of the third International Conference on Management of Innovation and Technology, Hangzhou City, China, 25-27 October 2002.

Ramsaran, C., (2003). Online banking comes of age. Bank Systems \& Technology. 40(11): 2-30.

Rogers, E. M., (1995). The diffusion of innovations ( $4^{\text {th }}$ ed). New York, NY: The Free Press.

Saadé, R., and Galloway, I. (2005), Understanding the acceptance of multimedia applications for learning, Issues in Informing Science and Information Technology, 2, 287-296. 
Sathye, M., (1999), Adoption of Internet banking by Australian consumers: an empirical investigation, International Journal of Bank Marketing, 17(7): 324-334.

Selim, H. M., (2003). An empirical investigation of student acceptance of course websites. Computers \& Education, 40: 343-360.

Sihombing, S. O., (2007). Students Adoption of the Internet in Learning: Applying the Theory of Acceptance Model. Proceedings of National Conference "Inovasi Dalam Menghadapi Perubahan Lingkungan Bisnis”, Jakarta: Universitas Trisakti.

Singh, S., (2012). An empirical investigation of the determinants of users' acceptance of E-banking in Singapore (A Technology Acceptance Model), International Journal of Management and Business Research, 2(1): 69-84.

Suh, B., and Han, I., (2002). Effect of Trust on Customer Acceptance of Internet Banking. Electronic Commerce Research and Applications, 1 (3/4): 247-263.

Venkatesh, V. (1999). Creation of Favorable User Perceptions: Exploring the Role of Intrinsic Motivation," MIS Quarterly, (23): 239-260.

Venkatesh, V. (2000). Determinants of Perceived Ease of Use: Integrating Control, Intrinsic Motivation, and Emotion into the Technology Acceptance Model, Information Systems Research 114): 342-365.

Venkatesh, V. and Davis, F.D. (1996), A Model of the Antecedents of Perceived Ease of Use: Development and Test, Decision Sciences 27(3): 451-481.

Venkatesh, V., and Morris, M.G., (2000). Why don't men ever stop to ask for directions: Gender, social influence and their role in technology acceptance and usage behavior? MIS Quarterly, 24(1): 115-139.

Wang, Y.S., Wang, Y.M., Lin, H.H., and Tang, T.I. (2003). Determinants of user acceptance of internet banking: An empirical study. International Journal of Service Industry Management, 14(5): 501-519.

Weisberg, J., Te'eni, D., and Arman, L. (2011). Past purchase and intention to purchase in e-commerce: The mediation of social presence and trust. Internet Research, 21(1): 82-96.

Wong, C. C., and Hiew, P. L., 2005. Mobile Entertainment: Review and Redefine. Paper presented at the IEEE 4th International conference on Mobile Business, Sydney, Australia.

Yu, C.S., and Lo, Y. F., (2007). Factors encouraging people to adopt online banking and discouraging adopters to use online banking services. Proceeding of Business and Information. International Conference on Business and Information, Tokyo, Japan. 
Kazi /International Journal of Finance \& Banking Studies, Vol 2, No 2, 2013 ISSN: 2147-4486

Zeithaml, V. A., Parasuraman, A., and Malhotra, A., (2002). Service quality delivery through Web sites: a critical review of extant knowledge. Journal of the Academy of Marketing Science, 30(4): 362-375. 